https://helda.helsinki.fi

\title{
Human rights and the digital
}

\section{Karppinen, Kari}

Routledge

2017

Karppinen , K 2017 , Human rights and the digital . in H Tumber \& S W (eds), The

Routledge Companion to Media and Human Rights . Routledge Media and Cultural Studies

Companions , Routledge , Abingdon, Oxon , pp. 95-103 . https://doi.org/10.4324/9781315619835-9

http://hdl.handle.net/10138/231230

https://doi.org/10.4324/9781315619835-9

acceptedVersion

Downloaded from Helda, University of Helsinki institutional repository.

This is an electronic reprint of the original article.

This reprint may differ from the original in pagination and typographic detail.

Please cite the original version. 
This is a preprint of a chapter to be published in the Routledge Companion to Media and Human Rights (2017), edited by H. Tumber \& S. Waisbord.

https://www.routledge.com/The-Routledge-Companion-to-Media-and-Human-

Rights/Tumber-Waisbord/p/book/9781138665545

\title{
Human rights and the digital
}

\author{
Kari Karppinen
}

\section{Introduction}

Terms such as "digital rights" and "internet rights" now have a prominent place in political and academic debates around the world. While not so long ago it was possible to argue that the perspective of human rights had only received marginal attention in debates on the global information society (Drake \& Jørgensen 2006: 5), it now seems that individual rights constitute a central normative framework for approaching policy issues related to new digital technologies and the internet.

The calls for the protection of digital rights have resulted in a number of reports, projects and political declarations. The United Nations World Summit on Information Society (WSIS) process (2003-2005) is often seen as the first global attempt to assert the status of human rights principles in the development and global governance of the information society. While views on its results in promoting human rights were mixed, in recent years the rhetoric of digital rights has gained even more prominence as several governments and international organizations have produced their own declarations on rights and freedoms in the digital age. ${ }^{1}$ Digital rights have also become a prominent cause for political activism and civil society organizations both nationally and globally (e.g. APC 2006; IRPC 2015; Padovani \& Calabrese 2014).

Declarations alone do not mean that human rights are realized in practice or that current communication and information policies would actually be guided by human rights consideration any more than before. The prominence of rights may also reflect the perception that human rights are increasingly threated in the digital era, as continuing concerns over new architectures of control and revelations of widespread surveillance practices online imply.

Few would deny that the political and regulatory choices related to digital technologies have profound impacts on freedom of expression, access to information, privacy, and a range of other human rights related to development,

\footnotetext{
${ }^{1}$ At the international level, these include reports by the United Nations Human Rights Council, UNESCO, and even OECD and G8, as well as regional declarations, such as the African Declaration on Internet Rights and Freedoms and several European Union and the Council of Europe documents. At the national level much attention was given to the Brazilian Civil Rights Framework for the Internet (2014), and its provisions on net neutrality, privacy and freedom of expression online. Following the NSA spying scandal and Edward Snowden's leaks, similar documents have been prepared by countless other national and international bodies.
} 
culture and social equality among other areas (for different perspectives, see e.g. Akrivopoulou \& Garipidis 2012; Јørgensen 2006; Klang \& Murray 2005). There are a range of concrete policy and legal issues that currently raise human rights concerns related to issues, such as net neutrality, copyright and piracy, surveillance and privacy, data protection, and content filtering. Aside from specific legal issues, human rights principles also bear upon broader concerns about the future development and governance of digital media, such as equal access to the internet or the "structural power" of dominant internet platforms and corporations who increasingly control data flows (e.g. Horten 2016).

As a widely recognized and institutionalized normative framework, human rights clearly offer a useful normative basis for these debates. Yet current debates on digital rights do not constitute a unified approach to concrete policy problems. It can be argued that the digital transformation has only exacerbated disagreements about the meaning and interpretation of relevant rights, the means by which they can be realized, and how they should be balanced with other concerns, such as security or economic efficiency. The convergence of digital media across borders and industry sectors has challenged existing normative and regulatory frameworks in communication policy and introduced new issues, tensions, and arenas of political contestation. Does the new digital environment then create a need for new human rights, and what kinds of institutions are needed to uphold and enforce these rights in the non-territorial, regulation-averse and rapidly changing digital environment?

Instead of focusing on individual regulatory issues or legal frameworks, this chapter takes a broader view of digital rights as emerging normative principles for the governance of digital communication environment. In this sense, the framework of digital rights is open to multiple narratives that reflect different political visions and interests. The chapter begins by first broadly outlining different perspectives from which the interface between human rights and new digital technologies can be approached. After that, the chapter reviews the evolution of digital rights discourses from the early emphasis on negative rights and the uncontrollable nature of digital technologies towards a broader agenda of digital rights and threats. Finally, the chapter highlights the variety of approaches to digital rights in academic research and in current digital rights activism. As the main thread, the chapter emphasizes that debates on digital rights do not constitute a fixed set of demands that can be ever fully settled or realized. Instead, the debates are can be seen as part of an ongoing process of negotiating and contesting the ethical frameworks and principles for the regulation of new digital technologies.

\section{Human rights and the digital transformation: four perspectives}

The interface between human rights and the new digital technologies can be approached from diverse angles and at different levels, including philosophical debates, concrete legal and policy analyses, studies of social movements and activism, and a range of more specific themes related, for instance, to development, gender, child protection, or cultural minorities' rights. Furthermore, rights can refer 
to existing formal, legally binding norms, but especially in non-legal discourses they are also used more broadly to refer to normative principles or ethical ideals, against which real-world developments are assessed (Mathiesen 2014). For the purposes of grasping the different of levels of debate, I highlight here four different perspectives in the digital rights debates.

The first, and perhaps dominant perspective, from which all new media technologies have been discussed, concerns how digital technologies extend and challenge existing communication related rights and freedoms, particularly freedom of expression. In both academic debates and popular commentary, much has been written on how digital technologies boost freedom of communication and democracy by opening up new opportunities for self-expression and political participation for new voices (e.g. Benkler 2006; Castells 2009). Yet many critical scholars remind us how the same digital tools can also be used for censorship and surveillance, and new forms of communicative inequalities and concentrations of power (e.g. Curran, Freedman \& Fenton 2013; McChesney 2013). Besides the vast attention given to the contentions between digital optimists and pessimists and their perspectives on the realization of communicative rights and freedoms, new digital technologies have at least revitalized and re-politicized legal, political and philosophical debates on the meaning and interpretation of free speech and its regulatory implications.

The prominent debates on freedom of expression and privacy protection, however, cover only part of the broader international human rights agenda (see Drake \& Jørgensen 2006: 5). Secondly, digital technologies have also been seen as an infrastructure for the realization and promotion of human rights more generally. As a 2011 United Nations Human Rights Council report notes, because of "the transformative nature of the digital technologies" the access to these technologies and the ability to utilize them effectively should be seen as a "an indispensable tool for realizing a range of human rights" (UNHRC 2011). Besides their obvious impact on freedom of expression, this perspective sees digital tools more broadly as tools that enable the promotion of broader human rights related goals, such as economic development, political participation, combating inequality, and societal progress in general. The perspective of digital technologies' facilitative role has also raised the question of whether access to the internet or other digital tools, should be seen as a human right in itself, which would create a positive obligation for states to ensure connectivity (De Hert \& Kloza 2012). As Mathiesen (2014) argues, internet access can be seen as a "derived human right" that stems from more primary human rights, whose realization increasingly depends on access to the use digital technologies.

Thirdly, beyond the debate on internet access as a human right, new technologies have generated demands of other, more specific new human rights. A good example is the right to data protection, including the ownership and fair use of personal data. Now protected in the EU Charter of Fundamental Rights, for instance, the right to data protection can be seen as a new right that branches off from established interpretations of privacy as an established human right. Another controversial example is "the right to be forgotten", which allows individuals to ask for outdated 
or irrelevant information about them to be removed from search results. As with all other new human rights, it can be argued that the proliferation of new rights might lead to the inflation and fragmentation of the human rights framework (De Hert \& Kloza 2012). However, the framework of human rights is historically not unchanging or locked, and as the current wave of internet rights declarations indicate, new rights emerge in response to new contexts and challenges.

Finally, the interface between human rights and the digital environment can also be approached from the perspective of the regulatory regimes or institutions needed to uphold and enforce rights. Beyond their impact on public communication, the digital convergence and the globalization of information flows have influenced the capacity of states to implement policies designed to fulfill citizens' communication rights (e.g. Flew, losifides \& Steemers 2016; Lunt \& Livingstone 2012). The global and distributed nature of digital media networks thus raises questions of "who has the authority and the ability to govern, and in response to what goals" (Mansell 2012: $171)$, and whether there a need for new global institutions or regulatory frameworks to enforce policies based on human rights principles (e.g. Mueller 2010; Brown \& Marsden 2013). In the context of internet governance, in particular, the new forms of global politics and transnational institutions are often discussed with terms such as multistakeholderism or network governance, which seem to imply that the locus of regulation has fundamentally shifted from states, and treaties between states, towards non-state actors and different types of soft governance.

While these perspectives are by no means exhaustive, they illustrate the range of human rights issues that digital technologies raise. Beyond these different levels of analysis, I will now turn to discuss the question of against whom, or what threats, digital rights are typically claimed.

\section{Negative and positive rights in the digital environment}

The distinction between negative rights, which protect individuals from unjustified government interference, and positive rights, which obliges states to guarantee individuals some basic goods, provides one way to examine the underlying ideals of the digital rights debate.

Historically, the debates on free expression and human rights in the new digital environment have been dominated by a negative rights perspective. Both academic and early activist debates largely focused on opposing governments' attempts to impose laws and restrictions on free speech and privacy on the internet, rather than focusing on the broader international human rights agenda and its issues, such as the rights to development, gender equality, non-discrimination, or the right to take part in cultural life (see Drake \& Jorgensen 2006: 5-6). As Ithiel de Sola Pool (1984: 10) argued in the early academic debates on new communication technologies, the question was "whether the electronic resources for communications can be as free of public regulation in the future as the platform and printing press have been in the 
past", or "whether that great achievement will become lost in the confusion about new technologies".

A decade later, A Declaration of the Independence of Cyberspace by John Perry Barlow (1996) reflected the same ideas even more dramatically:

Governments of the Industrial World, you weary giants of flesh and steel, I come from Cyberspace, the new home of Mind. On behalf of the future, I ask you of the past to leave us alone. You are not welcome among us. You have no sovereignty where we gather.

We have no elected government, nor are we likely to have one, so I address you with no greater authority than that with which liberty itself always speaks. I declare the global social space we are building to be naturally independent of the tyrannies you seek to impose on us. You have no moral right to rule us nor do you possess any methods of enforcement we have true reason to fear.

This often heard libertarian utopia conceived new digital technologies as independent of the terrestrial political, economic and legal systems, and as a naturally egalitarian and uncontrollable space for the exchange of information and free communication (Kreiss 2015). The idea that governments should not interfere in the development of digital technologies because it inevitably stifles innovation, creativity and individual rights is still familiar in current policy debates (Mansell 2012; Kreiss 2015). On the other hand, the idea that digital media are somehow naturally beyond terrestrial politics and its methods of enforcement has lost much of its conviction in the last two decades. Few would now deny that new digital technologies are intimately entangled in economic power relations and governmental and regulatory structures. While this is certainly the case in authoritarian societies like China, the Snowden leaks and other revelations of mass surveillance have increasingly revealed how states, often in cooperation with powerful corporations, aim to exert control also in western liberal-democracies (e.g. Horten 2016; Lyon 2015).

The UNESCO report on the new ecology of freedom of expression concludes: "The control of information on the Internet and Web is certainly feasible, and technological advances do not therefore guarantee greater freedom of speech" (Dutton et al. 2011: 40). Similarly the UN Human Rights Council (2011) has noted that: "States are increasingly censoring information online, namely through: arbitrary blocking or filtering of content; criminalization of legitimate expression; imposition of intermediary liability; disconnecting users from Internet access, including on the basis of intellectual property rights law; cyberattacks; and inadequate protection of the right to privacy and data protection". As another sign of increasing prominence of these concerns, the UNHRC appointed in 2015 a first special rapporteur on the right to privacy in the digital age. 
Despite recurring predictions of the diminishing role of states in communication policy, national policies thus remain key factors that influence the development and use of digital media (Goldsmith \& Wu 2006; Flew et al 2016). On the one hand, this points to the continued relevance of a negative rights perspective, and the basic function of human rights to vertically shield individuals against abuses of power by states. On the other hand, the exclusive focus on government censorship ignores how commercial and other types of power relations can also constrain digital rights and freedoms.

As Horten (2016) among others describes, a small number of large companies have "structural power" to shape access to information in the digital realm. A select few search engines and content platforms, and their algorithms determine what we can do, with abilities to track user behavior, control personal data, and give preference to or even block specific contents. These new algorithmic architectures of control, or "regulation by code" (Lessig 1999), now raise a broad range of human rights concerns over freedom of expression, privacy, and other potential forms of discrimination and manipulation. As a consequence, the assumption that free expression and other human rights exist if there is no government intervention, is a very narrow way to approach the interface between human rights and digital media (see Kenyon 2014).

In contrast to the early rhetoric that emphasized freedom from the state, in current policy debates around copyright and access to knowledge, net neutrality, and data protection, for instance, the choice is usually not between regulation and no regulation at all. In contrast to the imaginary of an uncontrollable virtual space, digital media are regulated all the time, although not always in a democratically accountable way, and they are intimately related to "terrestrial" economic and political power structures (e.g. Braman 2009; Goldsmith \& Wu 2006). Instead of a choice between freedom and non-freedom, digital policies are about conflicts between different interests and aims, and different modes of regulation promoting different values.

From a positive rights perspective, regulation is not seen only as an obstacles to the realization of human rights. Instead, it can be argued that the realization of human rights, broadly understood, creates obligations for policymakers to promote equality of access, limit the concentration of power in the hands of few, place restrictions on commercial forms of surveillance and censorship, and to create other means to protect vulnerable and weak online.

The perspective of positive rights thus presents a more complex discourse of digital rights as a counterbalance to the new inequalities and forms of control and domination in the digital environment. Instead of a dichotomy between individual rights and government control, human rights-based policies are increasingly seen as an alternative to industrial control and a more closed, market-led, ecosystems. In both academic and activist digital rights discourses, such non-state threats to digital rights include the commodification of communication, the creation of new oligopolies, and other forces that may create or exacerbate social and cultural 
inequalities (Curran, Freedman \& Fenton 2013; Fuchs 2013; Horten 2016; McChesney 2013).

In terms of freedom of expression, the positive rights approach thus emphasizes the structural preconditions for citizens' equal and effective use of public speech. Furthermore, the second and third generation human rights, such as the right to development or the right to participation in cultural life, relate even more clearly to equal conditions and opportunities to take advantage of digital tools (Jørgensen 2013). Instead of non-intervention, they raise the questions of the regulatory and institutional arrangements needed to actually protect and fulfill these rights (Mathiesen 2014).

In terms of this wider understanding of human rights, non-interference and the legal protection of individuals' negative rights are not sufficient to maintain realization of human rights. Instead, as Mansell (2012) argues, the anti-regulatory imaginary inherited from the early debates on internet freedom has actually favored established power structures and enabled the continuing concentration of power in the digital media.

\section{Paradigms and politics of digital rights}

Despite claims of how new technologies intrinsically either expand or threaten human rights, these dangers and opportunities do not emerge independently of politics and regulation. As McChesney (2013: 99) notes, the entire realm of digital communications largely resulted from state intervention and government subsidized research, and even the lack of intervention in its development is a political decision. The different narratives associated with digital rights thus involve different political assumptions with complex implications for regulation and policy.

Much has been written on how new digital technologies and uses have disrupted existing frameworks and paradigms of media and communication policy. In the converged digital environment, distinct normative and regulatory traditions associated with previously separate media (print, broadcasting, telecommunications) have clashed, and as Duff (2012: 6) argues, the information society has inherited "a baggage of discordant normative traditions" - and a need for a new and rigorous normative debate on values and principles that public policies should be based on. Van Cuilenburg and McQuail's (2003) speak of an emerging "new communications policy paradigm", which is to reflect entirely "new political ideas and social values". Similarly, Mansell (2012: 4) argues that the dominant imaginaries of the internet as an uncontrollable or market-driven space, controlled by corporations and software engineers, has led to paralysis of regulatory imaginaries and a need for new imaginaries to "guide the evolution of the communication system along a pathway that is more consistent with aspirations for the good society".

While human rights clearly provide a normative basis for these debates, the perspective of rights itself can be associated with several different normative 
frameworks. Jørgensen (2013) argues that debates on human rights challenges in the context of the internet and information society involve different framings which highlight different human rights aspects: The infrastructure dimension focuses on the internet as a global resource that enables communication; the public sphere perspective highlight the internet as a public space for democratic participation; the media dimension draws attention to the internet as a new media platform, and its differences with conventional media, and finally the cultural dimension focuses on the social norms and practices of the internet.

In the academic literature, several scholars have approached the new digital policy problems from the normative perspective of the public sphere and democratic participation (Dahlberg 2011; Lunt \& Livingstone 2012). Others have approached the same problems from a distributive justice perspective, emphasizing the importance of equal access and the fair distribution of information resources (Duff 2012; Schejter \& Tirosh 2015). Yet another perspective, especially pertinent in the debates on digital technologies and development (e.g. Kleine 2013), is provided by the "capabilities" approach to human rights, and its focus on the real communicative opportunities that people enjoy and the structural preconditions that they entail. All of these approaches employ the framework of human rights, yet they frame the normative questions differently and focus on different aspects of freedom, equality and rights in the digital era.

Besides academic debates, a growing range of social movements and digital activism groups have framed their aims and activities in the language of human rights. These movements do not either share a fixed conception of digital rights but cover various positions and ideologies.

The spectrum of these movements include established human rights organization, such as Amnesty International or Human Rights Watch; more specifically digital rights and information policy oriented organization like the Electronic Frontier Foundation or the Internet Rights and Principles Coalition; and even new political parties like the Pirate Parties in different countries. Many of the digital-rights groups' work still reflects the ideals of the early cyberliberties movements, which largely mobilized against rights violations by governments around the world (Drake \& Jorgensen 2006; Dahlberg 2011). On the other hand, newer digital rights movements, such as the Pirate Parties born in Northern Europe, have adopted a different type of thinking, which combines cyberlibertarian ideals with "cultural environmentalism" and the notion of "commons" to defend internet culture against both corporate and state colonization (Burkart 2014).

Yet other strands of communication rights activism focus more on the democratic and participatory aims associated with digital technology. The Communication Rights in the Information Society (CRIS) Campaign, for example, which mobilized a range of civil society organizations around the WSIS process in the early 2000s, defended a broader conception of "communication rights", which included not only negative freedoms but also positive rights of individuals to access and effectively deploy 
information and knowledge to promote democratic participation and the diversity of cultures and identities online (Alegre \& Ó Siochru 2005; Mueller et al 2007).

Various groups and movements with less organizational unity and more free-form activities and causes, such as Wikileaks, Anonymous, and even individual hacktivists, have emerged to defend human rights and freedom of information against various forms of restrictions in the digital world (Beyer 2014; Brevini et al 2013). Many of these have been seen as disruptive forces, which bring attention to a range of injustices and political issues, without necessarily following any specific political program or manifesto. While all of these groups claim to promote human rights, there is also criticism of their activities. Sorell (2015: 7), for example, criticizes the means and forms of Wikileaks and Anonymous for lack of transparency, arbitrary selection of causes, and lack of concern for the rights of their "targets", which can make their activities even "subversive of central tenets of human rights".

Rather than a specific framework or a paradigm, digital rights can thus be understood as a broad umbrella framing for a host of normative ideals. Beyond their status as existing legal obligations, rights can be articulated with a variety of framings and associations employed by different actors for different purposes. From this perspective, one crucial challenge for research on human rights and in the digital context is to clarify the concrete policy and practical implications of these different alternative visions.

\section{Conclusions}

Instead of focusing on human rights as an institutionalized legal framework, this chapter has focused more on debates on digital rights as expressions of different political and ideological visions and interests. The emphasis on the contested nature of rights does not mean to understate the importance of human rights as an established, legally defined and internationally recognized framework that can be invoked to challenge state and commercial surveillance, digital censorship, and various other forms of discrimination and rights violations. As a counterforce to other interests that drive the development of digital policies, such as state security, surveillance, and corporate influence, upholding human rights principles as existing legal norms is clearly a central task for policymakers and researchers.

Beyond this task, however, human rights also have another role in providing a longterm normative vision for the information and communication policies that are taking shape. In this broader meaning, the current academic and political debates on digital rights and their meaning are about negotiating and contesting the values and principles that guide future policies. This is no different from older media, where questions about the meaning and realization of communication rights, and whether policymakers should refrain from intervention or actively promote citizens' rights to diverse information, are continually contested. In the digital context, the number of policy issues and their complexity has only increased, which means that the debates 
on "digital rights" and their implications for regulation are not likely to be settled any time soon.

\section{References}

Akrivopoulou, C. \& Garipidis, N. (eds.), 2012, Human Rights and Risks in the Digital Era. Globalization and the Effects of Information Technologies, IGI Global, Hershey, PA.

Alegre, A \& Ó Siochrú, S 2005, Communication rights. In A Ambrosi, V Peugeot \& D Pimienta (eds.), Word matters. Multicultural perspectives on information societies, C\&F Éditions, Caen.

APC, Association of Progressive Communication 2006, APC Internet Rights Charter, viewed 10 April: https://www.apc.org/en/node/5677/

Braman, S 2009, Change of State, MIT Press, Cambridge, MA.

Brevini, B, Hintz, A, McCurdy, P 2013, Beyond Wikileaks: Implications for the Future of Communications, Journalism and Society, Palgrave, Basingstoke.

Barlow, P 1996, A Declaration of the Independence of Cyberspace. Available at: http://www.eff.org/cyberspace-independence

Benkler, Y 2006, How Social Production Transforms Markets and Freedom, Yale University Press, New Haven and London.

Brown, I \& Marsden, C 2012, Regulating Code. Good Governance and Better Regulation in the Information Age. MIT Press, Cambridge.

Burkart, P 2014, Pirate Politics. The Information Policy Contests. MIT Press, Cambridge, MA.

Castells, M 2009, Communication Power. Oxford University Press, Oxford.

Curran, J, Fenton, N, Freedman, D 2013, Misunderstanding the Internet. Routledge, London \& New York.

Dahlberg, L 2011, 'Re-constructing digital democracy: An outline of four "positions"' New media \& society, Vol 13, No 6, pp 855-872.

De Hert, P, Kloza, D 2012, 'Internet (access) as a new fundamental right. Inflating the current rights framework?', European Journal of Law and Technology, Vol. 3. No. 3. Available at: http://ejlt.org/article/view/123/268 
Drake, W J \& Jørgensen, RF 2006, 'Introduction', in Human Rights in the Global Information Society, MIT Press, Cambridge, MA.

Duff, A 2012, A Normative Theory of the Information Society, Routledge, New York.

Flew, T, losifides, P \& Steemers, J (eds) 2016, Global Media and National Policies. The Return of the State. Palgrave, Basingstoke.

Fuchs, C 2013, Social Media: A Critical Introduction. Sage, London.

Goldsmith, J \& Wu, T 2006, Who Controls the Internet? Illusions of a Borderless World. Oxford University Press, Oxford \& New York.

Horten, M 2016, The Closing of the Net. Polity Press, Cambridge.

IRPC, Internet Rights and Principles Coalition 2015, The Charter of Human Rights and Principles for the Internet, available at:

http://internetrightsandprinciples.org/site/charter/

Jørgensen, R F (ed) 2006, Human Rights in the Global Information Society. MIT Press, Cambridge, MA.

Jørgensen, RF 2013, Framing the Net. Human Rights and the Internet. Edgar Elgar, Cheltenham.

Kenyon, A 2014, 'Assuming free speech', The Modern Law Review Volume 77, Issue 3, pages 379-408

Klang, M \& Murray, A (eds.) 2005, Human Rights in the Digital Age, Glasshouse Press, London.

Kleine, D 2014. Technologies of Choice? ICTs, Development, and the Capabilities Approach. Cambridge: MIT Press.

Kreiss, D 2015, 'A vision of and for the Networked World. John Perry Barlow's A Declaration of Independence of Cyberspace at Twenty' in Media Independence: Working with Freedom or Working for Free?, eds J Bennett \& N Strange, Routledge, New York, pp. 117-136.

Lessig, L 1999, Code: And Other Laws of Cyberspace. Basic Books, New York.

Lunt, P \& S. Livingstone. 2012. Media Regulation: Governance and the Interests of Citizens and Consumers. Sage, London.

Lyon, D 2015, Surveillance after Snowden. Polity Press, Cambridge. 
Mansell, R 2012, Imagining the Internet. Communication, Innovation, and Governance. Oxford University Press, Oxford.

Mathiesen, K 2014, 'Human Rights for the Digital Age'. Journal of Mass Media Ethics Vol 29, No 1, pp. 2-18.

McChesney, R 2013, Digital Disconnect: How Capitalism is Turning the Internet Against Democracy. The New Press, New York.

Mueller, M L 2010, Networks and States. The Global Politics of Internet Governance. MIT Press, Cambridge, MA.

Mueller, M. L, Kuerbis, B and Pagé, C M (2007), 'Democratizing global communication. Global civil society and the campaign for communication rights in the information Society', International Journal of Communication Vol 1, pp. 267-296.

Padovani, C \& Calabrese A (eds) 2014, Communication Rights and Social Justice: Historical Accounts of Transnational mobilizations, Palgrave Macmillan, Basingstoke.

United Nations Human Rights Council (2011). Report of the Special Rapporteur on the promotion and protection of the right to freedom of opinion and expression, Frank La Rue. Available at: http://www2.ohchr.org/english/bodies/hrcouncil/docs/17session/A.HRC.17.27_en.p df

Schejter, A \& Tirosh, N 2015, "'Seek the meek, seek the just": Social media and social justice', Telecommunications policy Vol 39, pp. 796-803.

Sola Pool, I 1983, Technologies of Freedom, Harvard University Press, Harvard.

Sorell, T 2015, 'Human Rights and Hacktivism. The Cases of Wikileaks and Anonymous', Journal of Human Rights Practice Vol 7, No 3, pp. 391-410.

Dutton W H, Dopatka, A, Law, G; Nash, V 2011, Freedom of connection, freedom of expression: the changing legal and regulatory ecology shaping the Internet. Division for Freedom of Expression, Democracy and Peace, UNESCO, Paris. 